\title{
Talent Development Practices and Its Implications on Leadership Quality in Local Government Authorities in Tanzania
}

\author{
Yusuph Lameck Mashala \\ Local Government Training Institute, Dodoma, Tanzania \\ Department of Local Government Administration and Management \\ E-mail: m_lameck@yahoo.com \\ Lazaro Alman Kisumbe \\ Local Government Training Institute, Dodoma, Tanzania, \\ Department of Human Resource Management \\ E-mail: 1kisumbe04@yahoo.com
}

Received: Jul. 19, 2020 Accepted: Aug. 12, 2020 Online published: Sep. 13, 2020

doi:10.5296/jpag.v10i3.17369～URL: https://doi.org/10.5296/jpag.v10i3.17369

\begin{abstract}
Local Government Authorities (LGAs) in Tanzania are expected to fuel growth and respond timely to the demands of the community. They should therefore, ensure that the working capital is ready to embrace changes and can functionally as well as behaviorally take on key roles as effective strategic leaders. This study investigated the effect of talent development practices on leadership quality in LGAs in Tanzania. The study collected data from seventytwo (72) respondents from three LGAs (Kigoma Municipal, Kasulu and Mkuranga District Councils) through questionnaires. Data were analysed, using SPSS and presented using descriptive and inferential statistics. The overall findings suggested that training and development, employee engagement, leadership development, and employee sourcing positively affect leadership quality in LGAs. The study concluded that LGAs should have a characterized talent development strategy, which can be executed adequately to enhance talent progression.
\end{abstract}

Keywords: talent development, leadership quality, local government authorities, Tanzania 


\section{Introduction}

Over the past two decades since the inception of Local Government Reforms in Tanzania, Local Government Authorities (LGAs) have been construed as the important instruments of planning and implementing various development programmes. They play a vital role in enhancing the development and provision of social services in their respective jurisdictions and generally throughout the country. It is the commitment of government to see to it that all LGAs participate effectively in the provision of the quality services provided in the respective areas of jurisdictions. In this endeavour, LGAs are compelled to perform multiple roles and responsibilities, which include, inter alia, raising revenues and mobilizing community efforts to address specific community, felt needs. Additionally, the LGAs have the role to participate in the realization of the broad government objectives. These include the National Development Vision 2025, the Five-Year Development Plans 2016/17-2020/21, and effective participation in the transformation process of the social and economic development of Tanzania to sustain the recently attained middle-income status. Achieving these overarching roles and responsibilities as aligned to their powers stipulated under Article 145 (1), and functions under Article 46 (1) and (2) of the Constitution of the United Republic of Tanzania, LGAs need quality leaders devoted to develop and manage effective employee talents. In this case, quality leaders should be individuals who can make a difference to LGAs performance, either through their immediate contribution or, in the longer-term, by demonstrating the highest levels of potential. Talent Development and management practices deem to be a strategic priority and an important long-term investment, which LGAs need to pursue to realize the achievements of its primary roles and responsibilities. Lawler (2017) suggests that organizations, which recognize the importance of having agile talent employees, ensure long-term success and sustainability.

The concept of Talent Development has been widely used since 1997, thanks to Steven Hankin of Mickey and Company who coined the term 'the war of talent' and later fully discussed the topic of Talent Management in a book titled The War of Talent, written by Ed Michaels, Hellen Handfield-Jones and Beth Axelrod (Chambers, 1998; Axelrod, 2003; Beechler. \& Woodward, 2009). Since then, organizations around the world have acknowledged the need to embrace talent development practices to forecast and manage human capital more effectively by aligning business and strategic goal setting to prepare for the growth and expansions that occur within organizations (Martin, 2015). Appreciating the importance of Talent Development, (Michaels; Handfield-Jones and Axelrod, 2001) states that organizations which are struggling to prepare potential employees for leadership succession, they put processes in place that will identify and prepare High-Performing High-Potential (HIPO) employees to assume leadership positions. Thus, organizations wishing to succeed and pursue long-term competitive advantage must equip their employees with the requisite skills, knowledge, and behaviours necessary to lead with a spirit, vision, and teamwork (Wellins, Smith and Erker, 2009).

By implementing talent development practices, organizations do not only build a pipeline of agile leaders and successors but also stimulate and encourage a culture of learning by engaging the organizations' entire workforce for continuous development while 
simultaneously improving performance (Martin, 2015). In implementing the integrated talent development practices and processes as suggested by Lawler (2017), an organization can infuse effective methods, processes, and programs in addition to employee development. Besides, preparing leaders, maximizing their potential and increasing organizational effectiveness and ultimately realize its competitive advantage, adequate preparation of the human capital is imperative (Christensen Hughes, and Rog, 2008; Lockwood, 2006).

Due to the nature of services that they are expected to deliver to the community; LGAs in Tanzania possess the majority of the workforce. Nevertheless, they fail to attract, retain, motivate, and develop talented people (Benest, 2005; Pallangyo, 2009; Yusuph and Guohua, 2017). Thus, lack of talent development strategy and succession plans, lead to either losing most of the talented staff's inability to maximize the talents of their employees. The most pressing question is how to accelerate the process of nurturing and maturing leaders so that the absence of talent is never an impediment for LGAs to realize their goals. Moreover, many researchers have explained talent management with diverse views, but no studies have tested the concept empirically especially in LGAs in Tanzania. Studies have not intensively explored areas with the relative importance of the various components of talent management for the employees. Therefore, this study discusses employee perception regarding the effectiveness of talent development practices to see their implication on leadership quality in LGAs. Further, the study intends to bridge the knowledge gap in the literature by analyzing the talent development practices with the focus to training and development, employee engagement, leadership development, and employee sourcing to determine the implication of these on leadership quality in Tanzania LGAS, a case of Kigoma Municipal Council, Mkuranga and Kasulu District Councils. The study also examined the extent of the applicability of these aspects in the overall human development plans.

\subsection{Hypothesis}

The study sought to test the following four (4) hypothesis on the practices of talent development on leadership quality in LGAs.

\begin{tabular}{|l|l|}
\hline $\begin{array}{l}\mathbf{H}_{\mathrm{A1}} \text { : Training and Development has a } \\
\text { positive effect on Leadership Quality } \\
\text { in LGAs }\end{array}$ & $\begin{array}{l}\mathbf{H}_{\mathrm{A} 2} \text { : Employee Engagement has a positive } \\
\text { effect on leadership quality in LGAs } \\
\text { Leadership }\end{array}$ \\
$\begin{array}{l}\mathbf{H}_{\mathrm{A3}} \text { : Employee Development affect has a } \\
\text { positive effect on Leadership Quality in } \\
\text { LGAs }\end{array}$ & $\begin{array}{l}\mathbf{H}_{\mathrm{A} 4} \text { : Employee sourcing has a } \\
\text { positive effect on Leadership Quality } \\
\text { in LGAs }\end{array}$ \\
\hline
\end{tabular}

\section{Theoretical Framework}

\subsection{Perspectives on Talent Development}

Available. The literature conceives Talent management as a relatively recent concept in the business world (Tansley, 2011). There are quite antagonistic views among scholars on talent management when it comes to a detailed analysis of its conceptual attributes (Handley and Janet, 2012). Some scholars claim that the concept is nothing new but the old idea covered in the new wrapper (Mellahi and Collings, 2010). This critical perspective proposes that Talent 
Development represents just an updated version of Human Resource Management by improving similar attributes (Carmichael and Emsell, 2011). Another approach perceives Talent Management as a primary strategic tool of human resources in the organization whose main purpose is to acquire and retain talented employees (Horváthová and Mikušová 2010). Supporters of this view perceive the concept as part of HRM, which is specialized in the execution of the main human resource functions of hiring, training, and retaining potential employees (Carmichael and Emsell, 2011). Recently, research works by a number of scholars (Mensah, 2015; Oladapo, 2014; Egerova, 2013) have explained the talent management role in the organization as providing identification of key strategic position as well as utilizing available human resource instruments to attract, hire, motivate and keep employees according to their professions, skills, competencies and their levels of achievement. Based on this perspective, the main purpose of Talent Management in modern organizations is to boost workforce performance at each stage of the career ladder by encouraging employees to explore their potential and apply them in the organization (Cappelli, 2008). As suggested by Turabian, (2007), Talent development not only provides necessary tools for employees to achieve more in their professional life but also inspires employees to desire more in terms of career development. Thus, Aswathappa, (2005) confirms that an organization that recognizes talented employees, and use them effectively, demonstrate better performance.

Theorizing Talent development might be incomplete without an understanding of the word "Talent". Tansley, (2011) mentions that talent can be considered as a complex merger of employees' skills, knowledge, cognitive ability, and potential. Silzer and Dowell (2010) refer to talent as a pool of employees who are exceptional in their skills and abilities in either a specific technical area or a competency. Buckingham and Vosburgh, (2001) define as a person's recurring patterns of thought, feeling, or behavior that can be productively applied. Bethke-Langenegger, (2012) comments that we understand talent to be one of those workers who ensure the competitiveness and future of a company through their organization or job-specific qualification and knowledge, their social and methodical competencies, and their characteristic attributes such as eager to learn or achievement-oriented. Nijs et al. (2014) define talent as systematically developed innate abilities of individuals that are deployed in activities they like, find important, and in which they want to invest energy. However, Ulrich, (2011) opines that talent can mean whatever a business leader or writer wants it to mean since everyone has his or her idea of what the construct does not encompass.

Consequently, Talent development has broadly defined. Collings \& Mellahi (2009), state that talent management encompasses activities and processes that involve the systematic identification of key positions, which differentially contribute to the organization's sustainable competitive advantage. Scullion \& Collings (2011) state that talent management refers to organizational activities directed towards attracting, selecting, developing, and retaining the best employees in the strategic roles.

However, there is no single or concise definition of talent management. A synthesis of all the above definitions reveals that talent development is a broader issue and can be equated to a mindset. A survey of several other practitioners oriented literature describes talent 
management as a key component to effective succession planning while some others claim that talent management is attempting to make all the employees work at the top of their potential. In conclusion, it can be inferred that talent management is a wide term encompassing a long list of activities revolving around the creation of talent pools. Thus, these definitions provide the required background and serve as a curtain-raiser for the present study.

\subsection{Perspectives on Leadership}

The concept and meaning of leadership differ from one person to the other, and or based on prevailing situations. The word "leadership" has been used in various aspects of human endeavors such as businesses, politics, and or academics. Messick and Kramer (2004) state that the degree to which the individuals demonstrate leadership traits depends on his characteristics and personal abilities and the characteristics of the situation and environment in which he finds himself. Many scholars have provided the meaning of leadership; however, this study prefers the notable definition of leadership provided by Kouzes and Posner (1987) that leadership is an ongoing process of building and sustaining a relationship between those who aspire to lead and those willing to follow. The authors' views tend to explore the common patterns of action at the core of effective leadership, including authenticity, initiative, courage, and inspirations, as well as the abilities, to frame engaging opportunities, foster collaboration, empower others, and enabling individuals to accomplish extraordinary things.

The heart of organizational success depends on the leader's role to articulate a vision of what is possible and to motivate people to transform this vision into reality. This conforms to House and Shamir (1993) contention that it is the leaders' responsibility to convert the values, needs, preferences, and aspirations of their followers from individuals into collective interests. Various leadership styles and approaches such as Transformational leadership, Relationship-focused leadership, coaching and, task leadership have been identified as significant for displaying leadership qualities and retain potential talents in organizations.

Transformational Leadership Style. Transformational leaders receive high recognition for taking control of the organization by conveying a clear vision of the team's goals, a marked passion for the work, and an ability to make the rest of the group feel recharged and energized (Hawkins, 2017). Further, Transformational Leadership distinguishes itself as one of the most suitable types of leadership to guide organizations towards change and innovation (Hermosilla, et. al. 2016). Besides, Wildermuth and Pauken (2008) confirm that transformational leadership styles could improve employee engagement and inspire followers to adhere to a common vision.

Task focused Leadership Style. Various leaders employed a range of strategies to identify and retain talented employees in the acquired firm. Task-focused leaders tend to emphasize retaining talent in key positions because they can be crucial for the stability of the organization. Colbert and Witt (2009), maintain that goal-focused leaders underscore the importance of goal achievement, and use policies and practices to clarify goals and ensure subordinates' goal achievement. Moreover, goal-focused leaders are likely to understand what is expected of them by the organization, and what is required of them in their role as 
managers (Pratoom, 2018). Consequently, Task- focused leaders identify and retain strategically important positions that contribute enormously to the competitive advantage of the organization. Besides, task-focused leaders tend to differentiate talent based on performance, thereby exerting a positive influence on talent retention.

Relationship Focused Leadership Style. Leaders who adopt a relationship-focused leadership style tend to use the employment relationship as a strategy for identifying and retaining talented people. Consistent with earlier research (Wong and Leung, 2001), relationship-oriented leadership focuses on personal development, relationship building, and creating a positive work environment. The idea behind this is that a happy, motivated team will work to the best of their abilities and get things done. Zhanget. al. (2015) presuppose that relationship-oriented leaders are very personable, their door is always open and they have a genuine interest in the wellbeing of their staff. This style allows a leader to support and take care of his subordinates in a way that enables them to perform to the best of their ability, free from distractions and emotional burdens. Supporters of this style maintain that harmony within the workforce is often good as social cohesion is promoted ( $\mathrm{Li}$ and Blume, 2018).

Coaching Leadership style. Meyers, (2012) argues that coaching leadership style helps employees develop personally and with a long-term perspective. Simultaneously, the leader supports and challenges colleagues, with the intent of helping them achieve their individual development goals. Supporters of this approach also believe that a coaching leadership style is most effective when managers want to help their employees build lasting personal strengths. Besides, the style is accused to not affect when employees are not open to feedback or are not willing to learn (Benincasa, 2012). However, Ellinger and Bostrom (2002) maintain that leaders who practice coaching leadership style effectively, have empathy for and trust in others, less need for control and directing, a desire to help others develop, openness to feedback and personalized learning and a belief that most people want to learn. Subsequently, Leaders who adopt a coaching leadership style tend to attach importance to incentives in the form of employee development, such as training programs, thereby exerting a positive influence on successful talent retention. Employees value highly the incentives in the area of personal career development, such as comprehensive training, which increases their motivation to stay with the organization.

\subsection{Conceptual Framework}

Based on scholarly views on the perspectives of Talent Development and its implications in leadership in LGAs, the conceptual framework is developed. The framework presents the roadmap of the study showing the talent development and quality of Leadership quality as shown in Figure 1. 


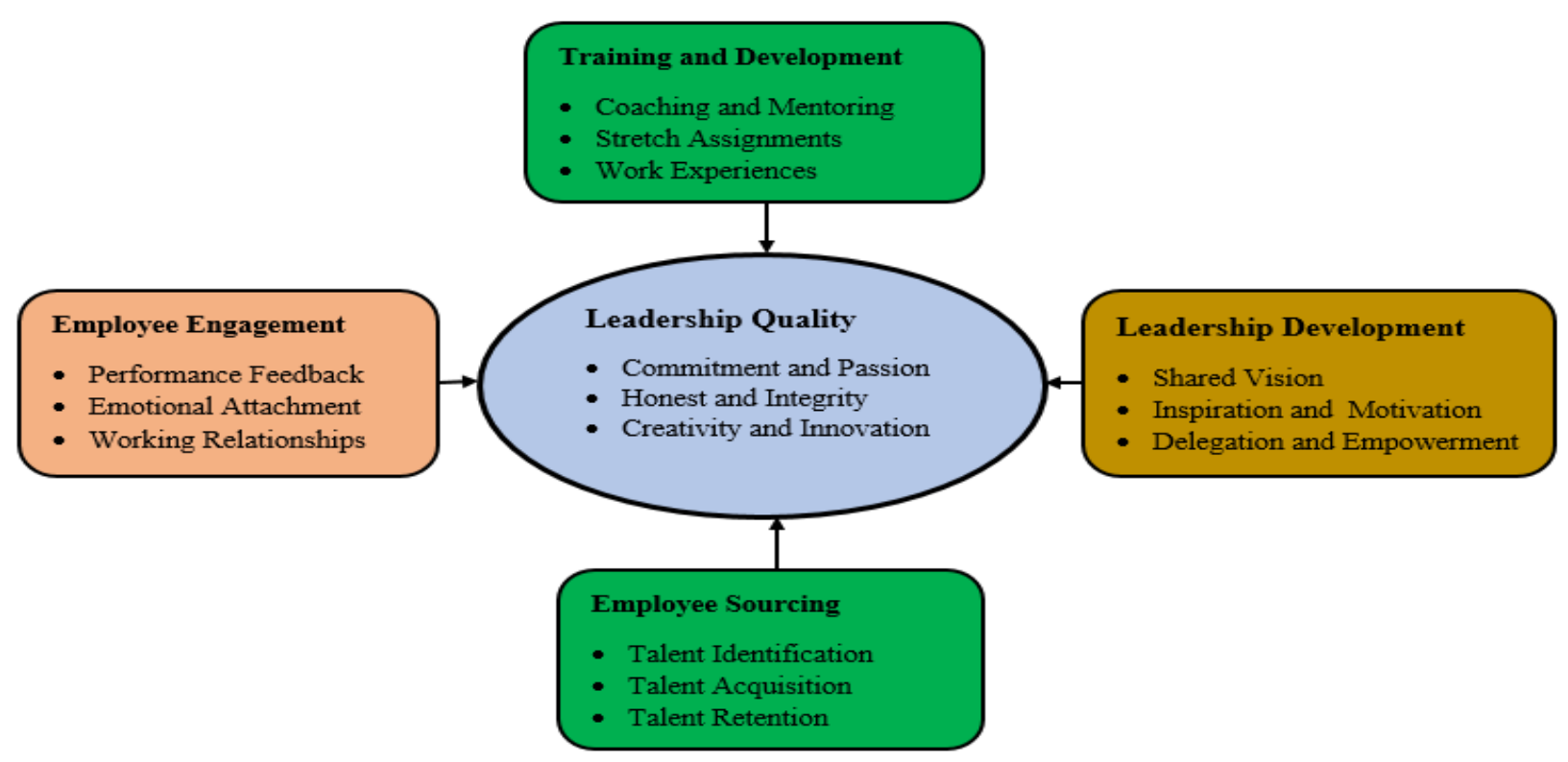

Figure 1. Conceptual Framework of the Study

Source: Researchers' construct based on empirical reviews

Training and Development, employee engagement, leadership development, and Employee Sourcing are the key talent development practices (independent variables) applicable in the field of Human Resource Management. How these practices are implemented bear implications on the quality of leadership in LGAs.

\section{Methods}

This study employed a cross-sectional survey design. The target population was stratified into three (3) strata. Purposive sampling was used to select the sample population from each Councils as shown in table 1.

Table 1. Sample Size by Council

\begin{tabular}{ccc}
\hline Council & Frequency & Sample Size \\
\hline Kigoma MC & 61 & 24 \\
Kasulu DC & 61 & 24 \\
Mkuranga DC & 61 & 24 \\
\hline Total & $\mathbf{1 8 3}$ & $\mathbf{7 2}$ \\
\hline
\end{tabular}

Source: Field Data 2018

Further, the target population of the study was employees from each targeted LGA. Selection criteria were given to Council Directors, Heads of Departments/Sections, and other middle officers falling in each department/section mostly holders of at least a bachelor's degree. A selection of these categories was because they were knowledgeable about the talent development practices adopted by each respective council. In this case, a sample population of 72 respondents was drawn from the targeted population as indicated in Table 2. 
Table 2. Sample Size by Employees Category

\begin{tabular}{ccc}
\hline Employee Category & Target Population & Sample Size \\
\hline Council Directors & 3 & 3 \\
Heads of Departments/ Sections & 60 & 45 \\
Middle Officers & 120 & 24 \\
\hline Total & $\mathbf{1 8 3}$ & $\mathbf{7 2}$ \\
\hline
\end{tabular}

Source: Field Data 2018

A semi-structured questionnaire was employed to collect data for the study. The researchers in collaboration with the Human Resource Officers of three councils administered the questionnaire to 72 respondents as shown in Table 2. We analyzed and presented through descriptive and inferential statistics, whereas multiple linear regression analysis was performed to establish the relationship between the dependent and independent variables.

\section{Results}

\subsection{Demographic Character Tics of Respondents}

\section{Sex and Age of Respondents}

A total of 115 respondents of varying ages and sex participated in this study. Figure 2 and summarizes the respondents' sex and age.

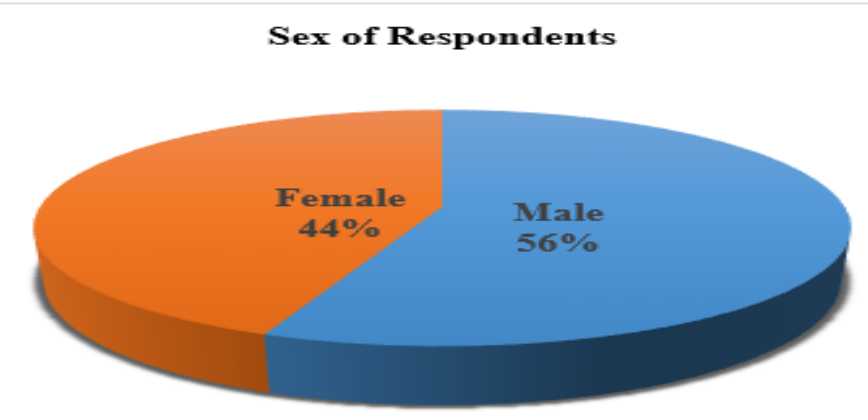

Figure 2. Respondents' Sex

Source: Field Data 2018

From the findings, $56 \%$ of the respondents were male, while $44 \%$ were female. This indicated that the study indicated that both males and females were included in the study with males taking a reading interest in the study. This reflects that the male personnel hold most of the senior human resource positions. Regarding respondents' age, distributions in this study are summarized in Figure 3. 


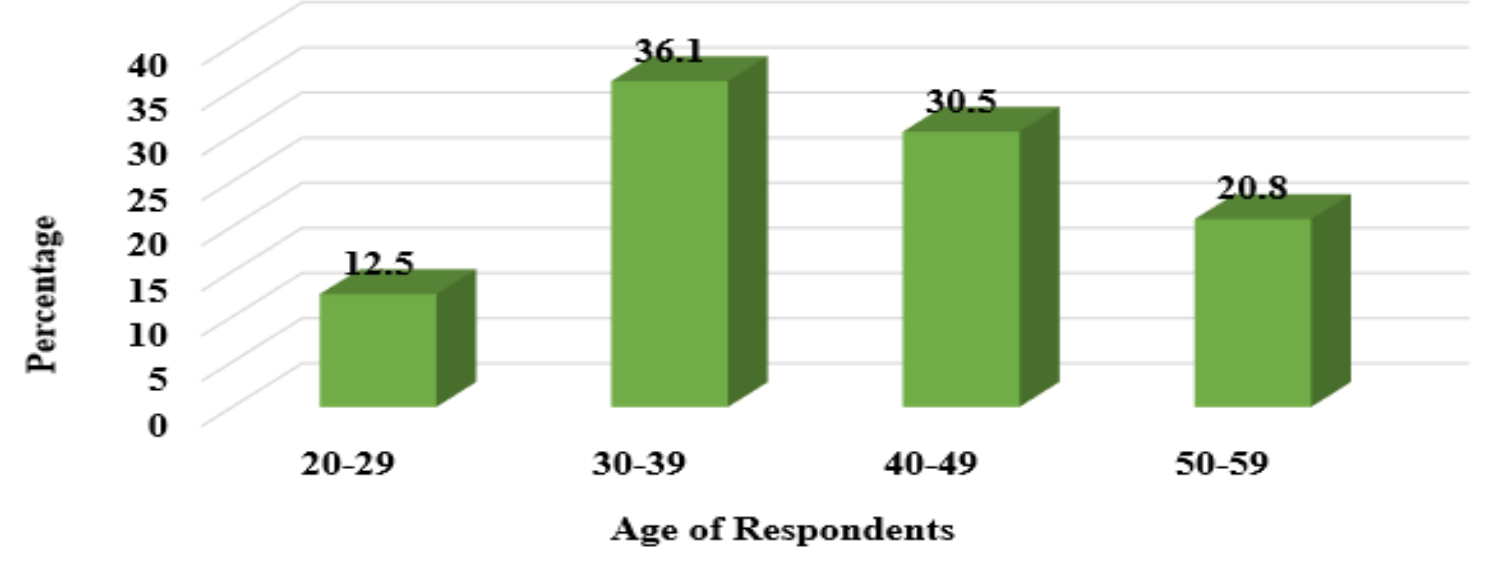

Figure 3. Age of Respondents

Source: Field Data 2018

Generally, as summarized Figure 3 shows that $36.1 \%$ of the respondents were aged 30-39 years, $30.5 \%$ were aged $40-49$ years and $20.8 \%$ were aged $50-59$. The number of respondents with both extreme lower and higher ages. Only $12.5 \%$ of the respondents were aged 20-29. These results indicate adequate age distribution among the respondents.

\subsection{Training and Development of Leadership Quality}

Responses were sought on the extent to which training and development are perceived to influence the quality of leadership in LGAs. The responses are summarized in Figure 4.

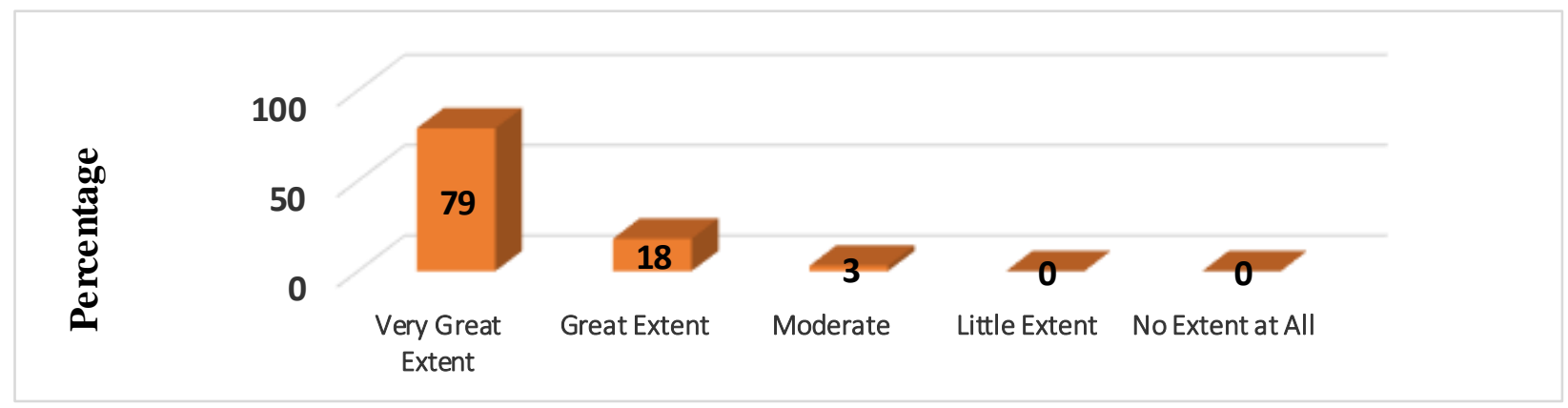

Figure 4. The Extent to which Training and development affect Leadership Quality Source: Field Data 2018

Figure 4 shows that $79 \%$ responded perceived that training and development contributed to the Very Great Extent on the quality leadership in LGAs. On the other hand, 3\% of the respondents opined that training and development moderately affected the quality of leadership. The overall results imply that majority of participants agreed that training and development affect leadership quality. 


\subsection{Employees' Engagement and Leadership Quality}

The responses regarding the extent of employees' engagement and its effects on the leadership quality are summarized in Figure 5

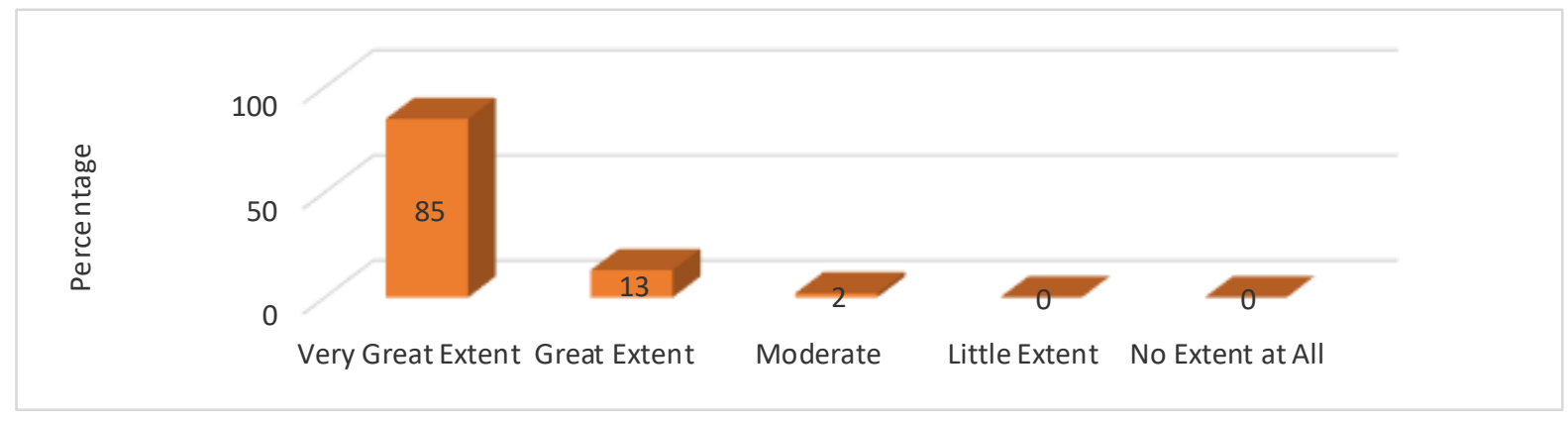

Figure 5. The extent to which Employee engagement affect Leadership Quality

Source: Field Data 2018

Results in figure 5 show that $85 \%$ of the respondents indicated that employee engagement affected leadership quality to a very great extent. Likewise, $2 \%$ of them opined that employees' engagement moderately affected leadership quality. However, neither low nor not at responses were selected. These results, therefore, imply that majority of respondents agreed that employee engagement has a positive effect on leadership quality.

\subsection{Leadership Development and Leadership Quality}

The effects of leadership development and leadership quality were tested. The responses are provided in Figure 6.

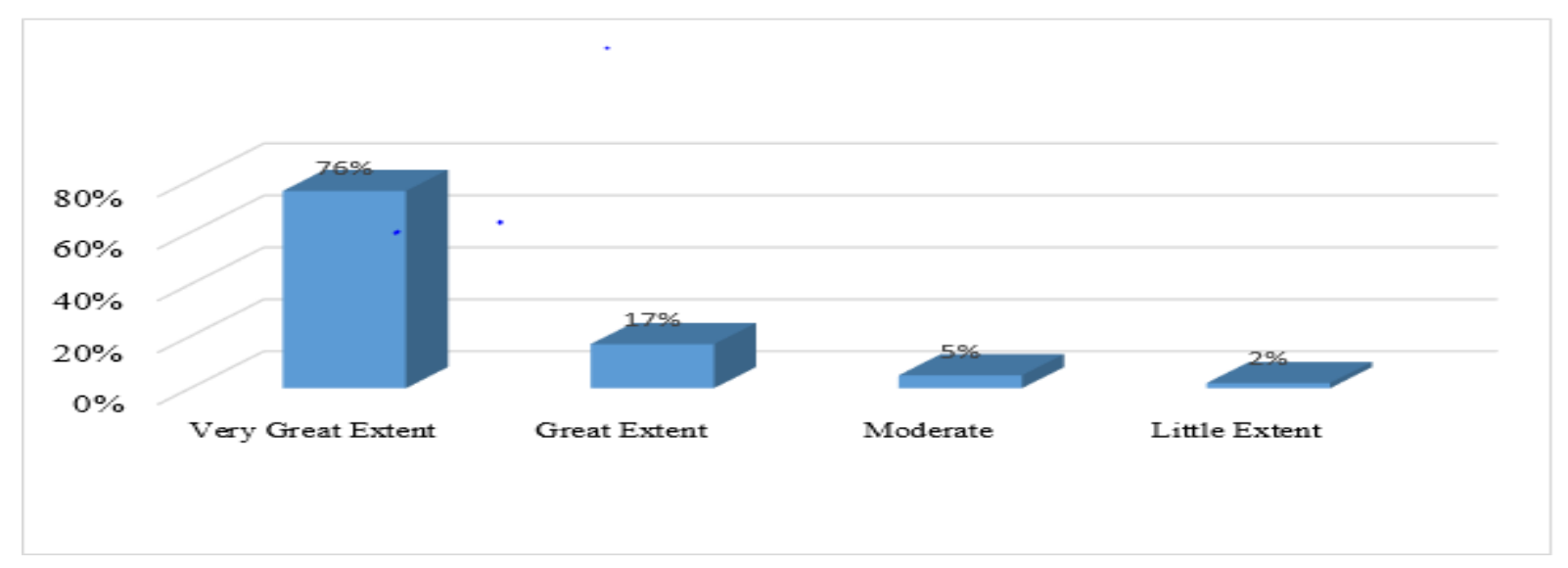

Figure 4. The extent to which Leadership development affects Leadership Quality

Source: Field Data 2018

The findings revealed that the majority of respondents (87\%) indicated leadership development efforts affected largely the quality of the leadership in LGAs. Similarly, about $10 \%$ of the respondents perceived that (leadership development efforts affected leadership to 
s great extent. These results imply that employee sourcing affects leadership quality at a very great extent level.

\section{Employee Sourcing and Leadership Quality}

Participants were asked to indicate their opinion regarding the extent of the effect of employee sourcing on Leadership Quality. The summary of the respondents is provided in figure 4.

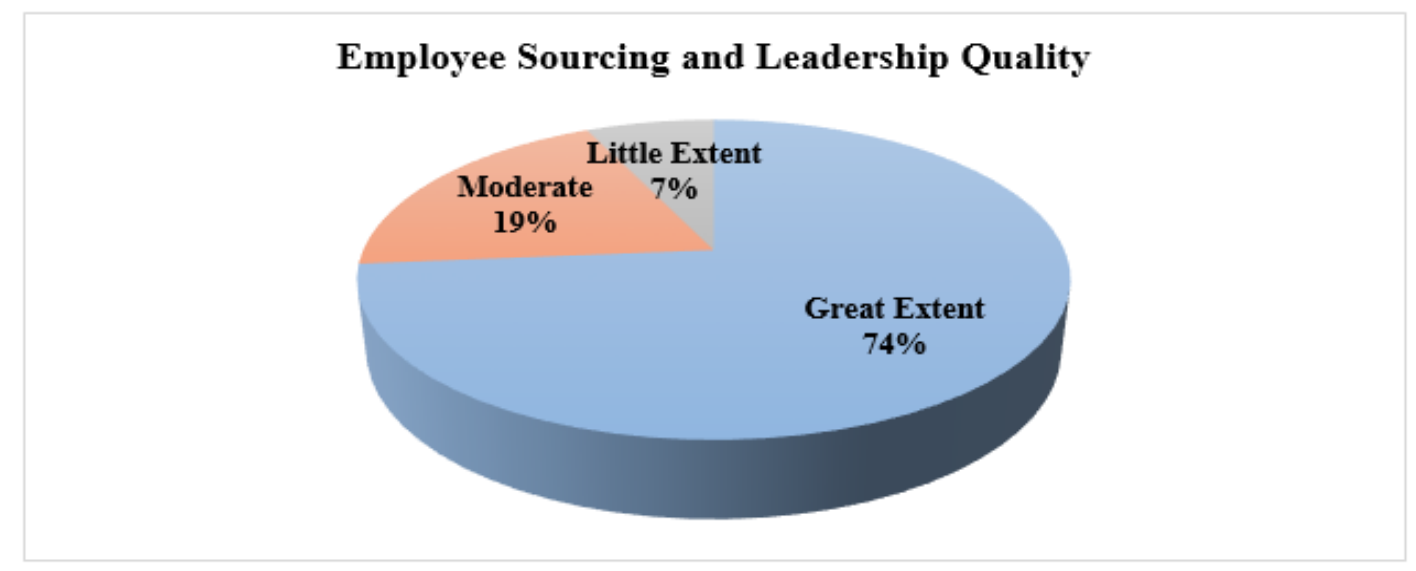

Figure 5. The extent to which Employee Sourcing affect Leadership Quality

Source: Field Data 2018

The findings in figure 4 show that $74 \%$ of the respondents were of the views that sourcing affected the quality of leadership to a great extent. Likewise, $19 \%$ indicated its effects were moderate, and $7 \%$ of them revealed that sourcing affected the quality of leadership to a little extent. Based on the results, it can be concluded that employee sourcing positively affects leadership quality in LGAs.

\section{Regression Analysis}

\section{Model Summary}

The multiple regression analysis was used to analyze the variations of the dependent variable due to the changes in independent variables. The results of the analysis are provided in the Model summary Table 3.

Table 3. Model Summary

\begin{tabular}{ccccc}
\hline Model & R & R Square & Adjusted R Square & Std. Error of the Estimate \\
\hline 1 & $.708 \mathrm{a}$ & .875 & .839 & .633 \\
\hline
\end{tabular}

Source: Field Data 2018

The study analyzed the variations of Leadership Quality due to the changes in training, employee sourcing, employee development program, and leadership grooming on the quality of leadership at LGAs. The analysis revealed that $83.9 \%$ of the variations in the quality of leadership in LGAs accrued from the changes in the independent variables i.e training and 
development, employees' engagement, leadership development, and employee sourcing. Thus, about $16 \%$ of the variations in the leadership quality in the study area is explained by the variables not included in the study. Such a variation of 83.9 indicates model fitness that the variables used in the study explain the variations in the dependent variable.

\section{Analysis of Variance}

The analysis of variance ANOVA was used to determine whether the data used in the study were significant as shown in Table 4.

Table 4. Analysis of Variance

\begin{tabular}{lrllll}
\hline Model & $\begin{array}{l}\text { Sum of } \\
\text { Squares }\end{array}$ & df & $\begin{array}{l}\text { Mean } \\
\text { Square }\end{array}$ & F & Sig. \\
\hline Regression & 2.534 & 2 & 1.267 & 5.455 & .024 \\
Residual & 9.307 & 40 & 2.327 & & \\
\hline Total & $\mathbf{3 . 4 6 5}$ & $\mathbf{4 2}$ & & & \\
\hline
\end{tabular}

Source: Field Data 2018

From the ANOVA statistics, the processed data (population parameters) had a significance level of 0.024 as indicated in table 8 . This implies that the data were ideal for making conclusions on the population's parameter, as the value of significance ( $p$-value) is less than $5 \%$. The F calculated was greater than F-critical $(3.23<5.455)$ an indication that the overall model was significant in predicting that training and development, employee engagement, employee sourcing, and leadership development significantly affect the quality leadership.

Table 5. Coefficients (Significance of the Variables in the Model)

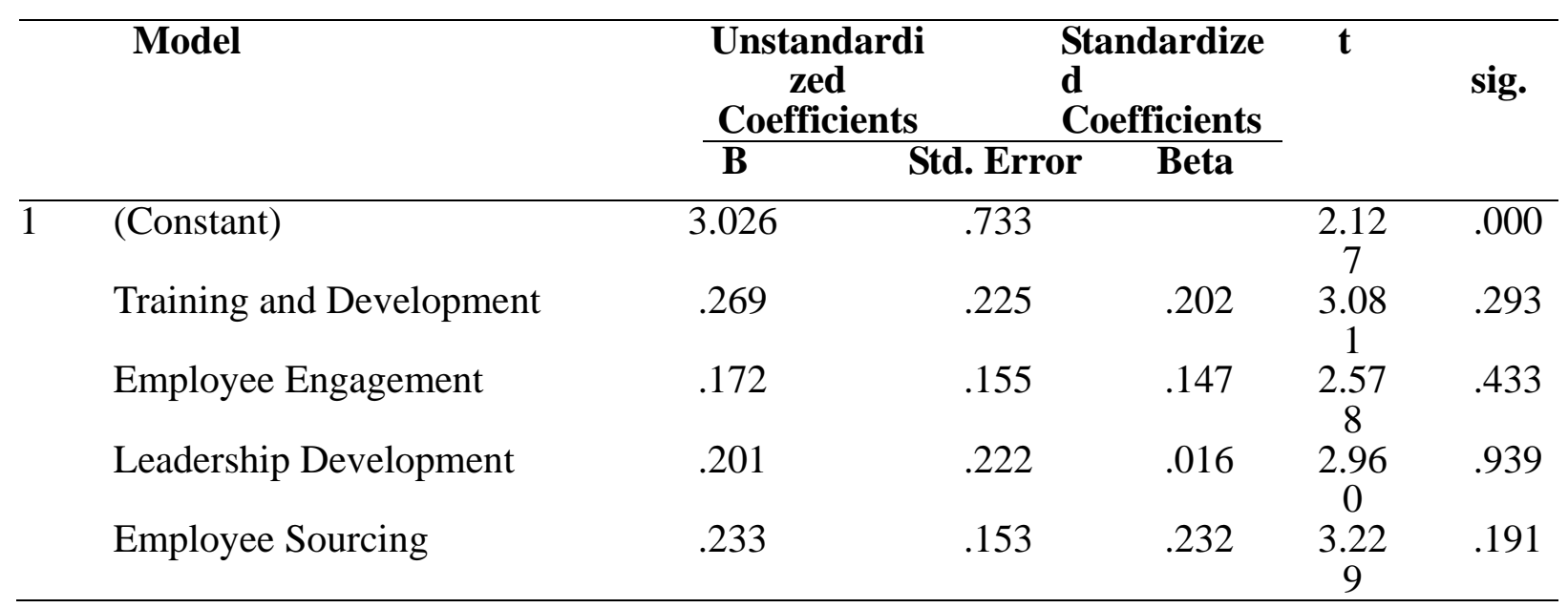

Source: Field Data 2018

The study multiple regression analysis was conducted to determine the relationship between independent variables and dependent variables. The regression equation was $Y=\beta 0+\beta_{1} X_{1}+$ $\beta_{2} X_{2}+\beta_{3} X_{3}+\beta_{4} X_{4}+\alpha$ ), Where $Y$ is the dependent variable (leadership quality), $X 1-X 4$ are independent variables; $X_{1}=$ training and development, $X_{2}=$ employee engagement, $X_{3}=$ leadership development and $\mathrm{X}_{4}=$ employee sourcing. Based on the study, the regression 
equation was translated as $Y=3.026+0.0 .269 X_{1}+0.172 X_{2}+0.201 X_{3}+0.233 X_{4}$. From the regression equation, the results show that holding all study variables constant, leadership quality in LGAs will stand at 3.026.

Moreover, if all the other variables are kept constant, a unit increase in training and development will lead to a 0.269 increase in leadership quality, and a unit increase in employee engagement will lead to a 0.172 increase in the leadership quality. Further, a unit increase in leadership development will lead to a 0.201 increase in leadership quality, and a unit increase in employee sourcing will lead to a 0.233 increase in leadership quality in LGAs. These results imply that training and development have the highest influence on leadership quality in LGAs, employee engagement the second, while leadership development is the third and employee sourcing is the last. Despite the level of effects, these results confirm that the study variables (training and development, employee engagement, leadership development, and employee sourcing) have positive but statistically insignificant effect leadership quality in LGAs. The findings suggest that the independent variables though are important to enhance.

\section{Discussion}

The results of this study have shown that both descriptive and inferential statistics confirm that talent development practices such as training and development, employee engagement, employee sourcing, and leadership development positively affect leadership quality in Local Government Authorities. In this case, embedded in the desire to achieve effectiveness in service delivery, LGAs should recognize the importance of developing and retaining the available talents to pursue higher responsibilities and meet customers' expectations. Also, LGAs have to establish strategies for attracting potential talents to join the respective LGA and retain them. Along with the understanding of the need to hire, develop, and retain talented people, the results of this study suggest that LGAs should be aware that they must manage talent as a critical resource to achieve the best possible results.

The results of the study have shown that training and have a positive influence on leadership. This is obvious as training employees increase their knowledge, skills, and competencies to perform challenging works in the organization; as such, it prepares them to perform future leadership responsibilities of the organization. These results are in line with Jehanzeb and Bashir (2013) who established that employee development programs are important for any organization to stay solvent and competitive in the market. Likewise, Lee and Bruvold (2003) reiterated that employee training and development is one of the most significant functions of human resource practices; it affects organizational outcomes by shaping employee behaviours and attitudes. Moreover, the findings of this study correspond to the observation by Whitener (2001) who documented that employee development creates trust among employees that their organizations value their contribution and care about their employability. Correspondingly, employee development programs facilitate greater obligation by employees towards the organization and, in turn, a willingness of employees to work hard to increase the organization's effectiveness.

Further, the findings of this study are in with the observations by Obisi (2011) who 
established that the ultimate aim of any training and development is to add value, as, without it, organizations will face difficulty in acquiring skills, competencies, and talents required. LGAs are duty-bound to establish employee assessment procedures that may take into consideration career development, training needs and development, and coaching and mentoring programs. Moreover, LGAs should not see employees' development programs as an expensive venture. Rather, they must encourage a learning culture through a serious approach to training and development employees. Besides, it should be understood that a leadership organization, is one, which continuously enhances the skills and talents of its entire workforce.

Secondly, the study has demonstrated that employee engagement affects leadership quality. The results match with Wendy (2012) who stated that employee engagement enhances effective leadership as it contributes to improved job satisfaction, commitment, and productivity of the organization. Similarly, Schaufeliet al. (2016) documented that employee engagement creates a positive, fulfilling, employees' work-related state of mind, and absorption of employees in the organization. Moreover, Anitha (2014) argued that when an employee is effectively engaged, clarity of ones' responsibilities becomes apparent and stirs commitment for performance. Generally, employee engagement is a critical factor in the creation of leadership quality. However, providing effective feedback to employees, communicating effectively to employees, and maintaining the quality of work relationships are key factors that LGAs should strive to work upon to harness the quality of leadership and maintain the highest competencies they need. London and Scott (2004) echoed that when paired with positive feedback, constructive comments, and a clear recipe for a change could enhance quality leadership for performance improvement. As he points out, employees are key factors in determining training, self-improvement, and career development need as they affect succession planning.

On leadership development, the results positive but statistically insignificant effect on leadership quality. They suggest that leadership quality depends on the quality of organizational efforts to nurture talented employees to be able to assume leadership responsibilities. These results match with Chung-Herrera and Lankau (2003) who confirmed that talent provides organizations with a key competitive advantage. This is possible where the process to identify and nurture next-generation leaders is in place. Similarly, Sherman and Bishop (2007) established that good leaders effectively develop, groom, grow and nurture the next succession of leaders who can quietly take the helm when the leader leaves without causing a ripple of concern. Consequently, the art of effective communication provides employees with important information about their jobs, organization, and feedback about their performance. Kikoski (1999) opined that communication could motivate, build trust, create a shared identity, and spur engagement; indeed, it can provide a way for individuals to express emotions, share hopes and ambitions, celebrate, and remember goals accomplishment. Based on the results, therefore, proper grooming on work methods, ethics, professionalism, skills, and competencies are important aspects of preparing a quality leader. Succession plans, coaching, effective delegation, succession planning, and coaching and mentoring efforts are often the best way to teach and expose prospective leaders to various challenging and 
motivating roles.

On Employee Sourcing, the results showed that it has positive but statistically insignificant effects on leadership quality in LGAs. The results imply that LGAs should maintain their current talents while doing their best to attract other potential talents through recruitment processes. Likewise, the results suggest that LGAs must develop a leadership culture where all employees' potentials are realized and developed. Assistance, mentoring, and coaching programs to the existence and or the newly recruited employees should be well provided to enrich their competencies in exercise their duties in line with their responsibilities. Though recruitment processes in LGAs are to some extent centralized as done by Recruitment Secretariat, especially to middle staff, efforts to identify potential talents for recruitment in key positions through their human resource plans are significant, as no way shall they execute their functions without talented staff. Rohitarachoon and Hossain (2012) echoed that, recruitment and selection function as a "vacuum" and "filter" that organizations employ to obtain proficient and skilled human resources for their organization. Therefore, LGAs would not be successful when executed by incompetent employees. Thus, attracting, hiring, developing, and retaining top talent is a key goal for any organization to enhance competitive advantages and performance improvements. From a similar perspective, Martin (2015) argued that organizations that can fuel growth and drive performance should ensure that employees are ready to embrace change and can functionally as well as behaviorally take on key roles within the organizations as effective strategic leaders. Regardless of the environment, human resource planning, recruitment, and development are the major concerns that prompt the readiness of talent for efficient and effective leadership.

\section{Conclusion}

From the study findings, one can infer that talent development practices have an implication on the leadership quality of any given organization. Better talent development practices are key to quality leadership and therefore it is of the essence for LGAs to have a characterized talent development strategy, which can be executed adequately to get the best fits for the vacant positions by promoting talented staff. It is, moreover, worth noting that developing talents in line with organizational culture yield many results in terms of productivity and competitive advantage. When employees are effectively developed, they can grow and develop positive behavior, which ultimately makes them more effective to pursue leadership roles, and processes that they undertake in the organization. It is understood that LGAs face some challenges in the processes of attracting and developing talents and retaining competent employees, including funding and some limitations regarding employing the exact number of employees as per their requirements. As such, they mostly run a shortage of employees and as for funds; they tend to direct much of their revenues to support social services at the expense of employee development. Despite the challenges, however, they have to strike the balance and give priority to human resource talent development as the most critical aspect in the realization of sustainable performance. Lastly, it is important to note that LGAs' only distinctive competence is its employees and leadership quality is the necessary catalyst. Therefore, coordinated effort is needed to convert employee potential into positive outcomes. As the findings of this study depicted high performing LGAs should be led by technically, 


\section{$\triangle 1$ Macrothink}

Journal of Public Administration and Governance ISSN 2161-7104 2020, Vol. 10, No. 3

conceptually, and interpersonally skilled leaders with the ability to empower and guide employee towards positive work behavior. Although leadership is a teachable skill, albeit difficult and time-consuming, systematic leadership development should be a strategic choice, representing a long-term investment in the LGAs future and that of its employees' growth. However, this study serves as a springboard for further scholars and researchers to investigate other factors that affect leadership quality in LGAs in Tanzania and how effective LGAs should manage varied talents in the manner that contribute to its performance. The conducted studies, perhaps, may come up with other concrete solutions that may refine and enrich practices and experiences critically needed in developing and retaining talented employees in LGAs.

\section{Reference}

Anitha, J. (2014). Determinants of employee engagement and their impact on employee performance. https://doi.org/10.1108/IJPPM-01-2013-0008

Axelrod, E. L., Handfield-Jones, H., \& Welsh, T. A. (2001). War for talent, part two. The McKinsey Quarterly, 9-9.

Beechler, S., \& Woodward, I. C. (2009). The global "war for talent". Journal of international management, 15(3), 273-285. https://doi.org/10.1016/j.intman.2009.01.002

Benest, F. (2005). It's the reality: The shrinking talent pool for local government managers. Public Management, 87(2), 14-19.

Benincasa, R. (2012). Leadership styles, and when you should use them. Fast Company.[Online] Available from: http://www. FastCompany. Com/1838481/6-leadership-styles-and-when-you-should-use-them (Accessed 21/11/2014).

Bethke-Langenegger, P. (2012). The differentiated workforce: Effects of categorization in talent management on workforce level. Unpublished working paper, 18.

Buckingham, M., \& Vosburgh, R. M. (2001). 21 Century Human Resources Function: It's the Talent, Stupid! Human Resource Planning, 17-23.

Buckingham, M., \& Vosburgh, R. M. (2001). The 21st-century human resources function: It's the talent, stupid! Identifying and developing talent, one person at a time becomes our defining challenge. Human Resource Planning, 24(4), 17-24.

Chambers, E. G., Foulon, M., Handfield-Jones, H., Hankin, S. M., \& Michaels III, E. G. (1998). The war for talent. The McKinsey Quarterly, 1(3), 44-58.

Christensen, H. J., \& Rog, E. (2008). Talent management: A strategy for improving employee recruitment, retention, and engagement within hospitality organizations. International Journal of Contemporary Hospitality Management, 20(7), 743-757. https://doi.org/10.1108/09596110810899086

Chung-Herrera, B. G., Enz, C. A., \& Lankau, M. J. (2003). Grooming future hospitality leaders: A competencies model. The Cornell Hotel and Restaurant Administration Quarterly, 
44(3), 17-25. https://doi.org/10.1177/001088040304400302

Colbert, A. E., \& Witt, L. A. (2009). The role of goal-focused leadership in enabling the expression of conscientiousness. J. Appl. Psychol., 94, 790-796. https://doi.org/10.1037/a0014187

Collings, D. G., \& Mellahi, K. (2009). Strategic talent management: A review and research agenda. Human resource management review, 19(4), 304-313. https://doi.org/10.1016/j.hrmr.2009.04.001

Collings, D. G., Scullion, H., \& Vaiman, V. (2011). European perspectives on tale management. European Journal of International Management, 5(5), 453-462. https://doi.org/10.1504/EJIM.2011.042173

Creswell, J. W. (2009). Research design: Qualitative, quantitative and mixed methods approaches. Thousand Oaks, CA: Sage.

Ellinger, A. D., \& Bostrom, R. P. (2002). An examination of managers' beliefs about their roles as facilitators of learning. Management Learning, 33(2), 147-179. https://doi.org/10.1177/1350507602332001

Hawkins, P. (2017). Leadership team coaching: Developing collective transformational leadership. Kogan Page Publishers.

Hermosilla, D., Amutio, A., Da Costa, S., \& Páez, D. (2016). Transformational leadership in organizations\&58; Mediating variables and long-term consequences. Revista de Psicología del Trabajo y de las Organizaciones, 32(3), 135-143. https://doi.org/10.1016/j.rpto.2016.06.003

Jehanzeb, K., \& Bashir, N. A. (2013). Training and development program and its benefits to employee and organization: A conceptual study. European Journal of business and management, 5(2).

Kikoski, J. F. (1999). Effective communication in the performance appraisal interview: Face-to-face communication for public managers in the culturally diverse workplace. Public personnel management, 28(2), 301-322. https://doi.org/10.1177/009102609902800210

Kim, S. (2003). Linking employee assessments to succession planning. Public Personnel Management, 32(4), 533-547. https://doi.org/10.1177/009102600303200405

Kouzes, J. M., \& Posner, B. Z. (1987). The Leadership Challenge: How to Keep Getting Extraordinary Things Done in Organizations. Jossey-Bass Wiley Imprint, San Francisco CA 94103-1741.

Lagace, M. (2006). Grooming next-generation leaders. Harvard Business School Working Knowledge. Retrieved August 1, 2008.

Lawler, E. E. (2017). Reinventing talent management: Principles and practices for the new world of work. Berrett-Koehler Publishers. 


\section{Mll Macrothink}

Journal of Public Administration and Governance ISSN 2161-7104 2020, Vol. 10, No. 3

Lawler, E. E. (2017). Reinventing talent management: Principles and practices for the new world of work. Berrett-Koehler Publishers.

Lee, C. H., \& Bruvold, N. T. (2003). Creating value for employees: investment in employee development. The International Journal of Human Resource Management, 14(6), 981-1000. https://doi.org/10.1080/0958519032000106173

Li, J., Laurence, G. A., \& Blume, B. D. (2018). How does supervisor-focused procedural justice explain the effects of person-focused leadership? The moderating role of leader-referenced relational-self. European Journal of Work and Organizational Psychology, 27(3), 387-399. https://doi.org/10.1080/1359432X.2018.1458713

Lockwood, N. (2006). Maximizing human capital: demonstrating HR value with key performance indicators. Retrieved November, 10, 2010.

London, M., Mone, E. M., \& Scott, J. C. (2004). Performance management and assessment: Methods for improved rater accuracy and employee goal setting. Human Resource Management: Published in Cooperation with the School of Business Administration, The University of Michigan and in alliance with the Society of Human Resources Management, 43(4), 319-336. https://doi.org/10.1002/hrm.20027

Martin, A. (2015). ScienceDirect Talent Management : Preparing a "Ready" agile workforce. International Journal of Pediatrics and Adolescent Medicine, 2(3-4), 112-116. https://doi.org/10.1016/j.ijpam.2015.10.002

Messick, D. M., \& Kramer, R. M. (2004). The Psychology of Leadership: New Perspectives and Research. Lawrence Erlbaum Associates, Publishers. New Jersey.

Michaels, E., Handfield-Jones, H., \& Axelrod, B. (2001). The war for talent. Harvard Business Press.

Mugenda, O. M., \& Mugenda, A. G. (2003). Research methods quantitative and qualitative approaches.

Murthy, P. S. (2010). Next Generation Talent Management-Perceptions. Social Science Research Network. https://doi.org/10.2139/ssrn.1653321

Nijs, S., Gallardo-Gallardo, E., Dries, N., \& Sels, L. (2014). A multidisciplinary review into the definition, operationalization and measurement of talent. Journal of World Business, 49 (2), 180-191. https://doi.org/10.1016/j.jwb.2013.11.002

Obisi, C. (2011). Employee training and development in Nigerian organisaitons: Some observations and agenda for research. Australian Journal of Business and Management Research, 1(9), 82.

Pallangyo, W. A. (2009). Impacts of the Local Government Reform Programme On Local Authorities' Human Resource Capacity in Tanzania (Doctoral dissertation, The University of Manchester).

Pratoom, K. (2018). Differential Relationship of Person-and Task-Focused Leadership to 


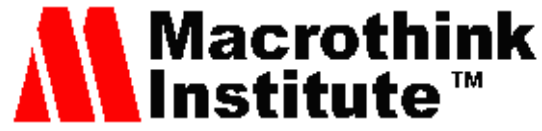

Journal of Public Administration and Governance ISSN 2161-7104

Team Effectiveness: A Meta-Analysis of Moderators. Human Resource Development Review, 17(4), 393-439. https://doi.org/10.1177/1534484318790167

Rohitarachoon, P., \& Hossain, F. (2012). Decentralized Recruitment and Selection in Thailand: Friend or Foe to Local Public Administration?. International Journal of Public Administration, 35(8), 553-561. https://doi.org/10.1080/01900692.2011.653513

Schaufeli, W. B., Bakker, A. B., Journal, S., \& May, N. (2016). Multi-Sample Study Job demands, job resources, and their relationship with burnout and, 25(3), 293-315. https://doi.org/10.1002/job.248

Sherman, R. O., \& Bishop, M. (2007). The role of nurse educators in grooming future nurse leaders. Journal of Nursing Education, 46(7). https://doi.org/10.3928/01484834-20070701-01

Silzer, R., \& Dowell, B. E. (2010). Strategic talent management matters. Strategy-driven talent management: A leadership imperative, 3-72. https://doi.org/10.1037/e518422013-320

Tansley, C. (2011), what do we mean by the term "talent" in talent management? Industrial and Commercial Training, 43, 266-274. https://doi.org/10.1108/00197851111145853

Ulrich, D. (2011). Integrated talent management. The executive guide to integrated talent management, 189-211.

Van Wart, M. (1998). Organizational Investment in Employee Development. In S. Condrey (Eds.), Handbook of Human Resource Management in Government, San Francisco: Jossey-Bass Publishers, 276-297.

Wellins, R. S., Smith, A. B., \& Erker, S. (2009). Nine best practices for effective talent management. Development dimensions international, 1-14.

Whitener, E. M. (2001). Do "high commitment" human resource practices affect employee commitment? A cross-level analysis using hierarchical linear modeling. Journal of management, 27(5), 515-535. https://doi.org/10.1177/014920630102700502

Yusuph, M. L., \& Guohua, W. (2017) Challenges for Implementing New Public Management Reforms in Local Government in Tanzania: Evidence from Six Selected Local Government Authorities.

Zhang, J., Ahammad, M. F., Tarba, S., Cooper, C. L., Glaister, K. W., \& Wang, J. (2015). The effect of leadership style on talent retention during merger and acquisition integration: Evidence from China. The International Journal of Human Resource Management, 26(7), 1021-1050. https://doi.org/10.1080/09585192.2014.908316

\section{Copyright Disclaimer}

Copyright for this article is retained by the author(s), with first publication rights granted to the journal.

This is an open-access article distributed under the terms and conditions of the Creative Commons Attribution license (http://creativecommons.org/licenses/by/4.0/). 